\title{
Assessing Soil Carbon Storage and Climate Change Mitigation in Biosolids Mine Reclamation Projects
}

\author{
A. Trlica, SYLVIS Environmental Services, Inc., New Westminster, BC, Canada \\ M. Teshima, SYLVIS Environmental Services, Inc., New Westminster, BC, Canada
}

\begin{abstract}
Carbon release due to land-use change and clearance of natural cover contributes significantly to anthropogenic climate change. Biosolids, the treated and stabilized solids from municipal wastewater treatment, have been applied to mines for decades to facilitate reclamation success. Using biosolids as a soil amendment in mine reclamation may help mitigate climate change by reversing carbon losses in land degraded by surface mining. However, the magnitude of long-term soil carbon storage increases with biosolids use in reclamation is largely unknown.
\end{abstract}

This study compared carbon storage in biosolids-amended and conventionally reclaimed mine soils several years after closure. Soil samples from 0-15 cm and 15-30 cm depths were taken from five surface mined areas, each containing sites reclaimed either with biosolids or with conventional reclamation approaches (e.g. topsoil + synthetic fertilizer). A focus of the sampling was to acquire information on sites with greater age since final reclamation (up to 27 years). Mines reclaimed with biosolids stored an average of $32.47 \pm 3.16$ tonnes of carbon per hectare more in the top $15 \mathrm{~cm}$ of soil than conventionally reclaimed sites; in the 15-30 cm soil layer differences in carbon storage were generally not significant.

Using estimates of carbon storage from one of the mine areas and other published studies, a life cycle assessment was conducted to estimate the net greenhouse gas (GHG) emissions from the use of biosolids in reclamation in the Pacific Northwest region of the United States. The assessment compared using biosolids to reclaim and reforest degraded land versus using biosolids in agriculture combined with conventional reclamation to forest. Accounting for GHG flows such as biomass and soil carbon increases and project-related fuel use, the assessment showed that using biosolids for reclamation had a greater GHG sink potential than conventional reclamation combined with agricultural biosolids applications. The results of the life cycle assessment show that coupling land reclamation with biosolids reuse carried a large potential for increases in on-site carbon storage.

Incorporating biosolids into a mine reclamation program can reduce reclamation costs as well as promote climate change mitigation through increased organic carbon storage on-site.

\section{$1 \quad$ Introduction}

Historic and ongoing processes of disturbance of natural land cover, such as deforestation, soil tillage, and land degradation have contributed substantially to the levels of $\mathrm{CO}_{2}$ in the atmosphere through release of the carbon stored in plant biomass and healthy soils (Canadell et al., 2007). Taking steps to reduce or reverse the net losses of carbon from its land storage pools, such as global efforts to encourage forest regrowth and reduce cropland plowing intensity, could provide economically viable strategies for slowing the rate of atmosphere $\mathrm{CO}_{2}$ increase, helping to mitigate climate change (Pacala and Socolow, 2004). Land disturbance during the course of surface mining activities leads to net $\mathrm{CO}_{2}$ emissions from the loss of carbon stored in biomass and in soils. In the reverse of this process, soil carbon stocks slowly rebuild during recovery after disturbance as, for example, in reclaimed coal mine soils in Ohio which accumulated carbon in the soil at a rate from 0.5-3.1 t C ha $\mathrm{yr}^{-1}$ over several decades after closure (Akala and Lal, 2001). Enhancing the speed and efficacy of mine reclamation efforts could therefore lead to greater greenhouse gas (GHG) reductions by more quickly removing carbon from the atmosphere and storing it in the recovering soil. 
Conventional approaches to reclamation of disturbed lands such as mechanical loosening of compacted soils, applying stockpiled topsoil and synthetic fertilizers, seeding with grass-legume seed mixtures, and mulching with straw or hydroseeding generally aid in vegetation recovery (Bowen et al., 2005; Jacinthe and Lal, 2007). However, soil conditions on reclaimed sites often remain poor due to low fertility, low organic matter content, compaction, inefficient nutrient cycling, diminished drainage, lack of stable soil aggregates or an active soil microbial community, and high bulk density limiting root penetration (Indorante et al., 1981; Sencindiver and Ammons, 2000). Soils reclaimed after mining often show altered physical and chemical properties that are inhibitive to plant growth (Haering et al., 2004), and have reduced capability for soil- and standing biomasscarbon recovery due to poor plant productivity (Amichev et al., 2004).

Applying organic materials such as biosolids, the stabilized solids removed during municipal wastewater treatment, as a soil amendment for mine reclamation can help to alleviate many of the deficiencies of reclaimed soil to produce a healthier matrix capable of supporting more stable and productive vegetation. Biosolids have been used for decades as an organic matter and nutrient source to reclaim soils disturbed by surface mining (Sopper, 1993), and have in many instances led to superior reclamation outcomes compared to traditional topsoil and fertilizer application alone (Haering et al., 2000; Roberts et al., 1988). Biosolids and other organic residuals are often more effective than conventional approaches to reclamation in restoring vegetation cover at sites with severe barriers to plant establishment, such as high soil acidity and contamination with heavy metals (Brown et al, 2003; Orndorff and Daniels, 2008).

As a result of biosolids amendment, reclaimed soils may also store more carbon than soils reclaimed conventionally with replacement topsoil and/or synthetic fertilizer alone (Tian et al., 2009). However, the longterm carbon storage effect of one-time biosolids applications during mine reclamation (a common practice with biosolids used in reclamation) is not extensively studied, and the quantity of carbon capable of being stored in this way is poorly defined. The current study addresses this information gap by comparing long-term ( $>5$ years) differences in carbon storage in degraded mine soils reclaimed with biosolids amendment and those reclaimed conventionally.

Research has also indicated that different end-uses of biosolids can carry with them different GHG emissions outcomes as a result of the emissions and offsets incurred over the life-cycle of their use, due mainly to differences in energy and fuel requirements in transport and processing (Murray et al., 2008). Soil carbon storage increases with biosolids amendment will also affect the life-cycle GHG emissions of any particular biosolids end-use option, and should be accounted for as well. After field quantification of the soil carbon changes with biosolids use in reclamation, this study continues with a life-cycle assessment of GHG emissions due to managing land with biosolids, incorporating onsite carbon storage as well as transport- and manufactured inputrelated emissions. The assessment compares two hypothetical reclamation scenarios constructed based on biosolids application experience in the Puget Sound region of Washington state: Biosolids used to reclaimed degraded land to forest, versus conventional reclamation of forest land, with diversion of biosolids to fertilize dryland agricultural fields. The life-cycle assessment allows for a more complete comparison of the GHG benefits of using biosolids in reclamation, as it includes the related and ancillary emissions associated with each utilization pathway and identifies potential environmental tradeoffs.

\section{$2 \quad$ Methodology}

Five closed mine areas in different geographical settings were sampled, each containing zones representing reclamation with biosolids and zones representing conventional reclamation (topsoil replacement and/or NPK fertilizer only). Sites were chosen for sampling to favour areas that had been reclaimed for longer periods of time (up to 31 years). The mine areas included a deactivated coal mine in central Washington, a former tailings impoundment lake at a hard rock copper-molybdenum mine in interior British Columbia; former settling ponds and a retired haul road at a sand and gravel mine in coastal British Columbia; reclaimed surface coal mines in eastern and central Pennsylvania; and closed sand and gravel mines located in New England (Massachusetts and New Hampshire). Site reclamation histories, including biosolids and other residuals application rates, were obtained from internal documents maintained by the mine operators and reclamation specialists, as well as from 
direct interviews with individuals involved in site reclamation. At the British Columbia sand and gravel mine, where conventional reclamation sites were unavailable for sampling, carbon storage was estimated based on the properties of the mine spoil and stored topsoil material. More detailed information on sampling methodology, site locations, soil treatments, prominent soil types and regional land use and climate at the individual mine sites is available in Trlica (2010).

At each mine area composited soil samples were collected from conventionally and biosolids-amended reclamation sites. The soil samples were collected from depths of 0-15 cm and 15-30 cm and segregated by depth. Sampling of soil up to $30 \mathrm{~cm}$ depth is a common technique in studies of mine soils (Akala and Lal, 2001; Shukla et al., 2005) and was selected for this study to capture the bulk of the mass of soil organic carbon assumed to be present in the sites, as well as the major differences in carbon storage that might have occurred as a result of reclamation approach. In undisturbed soils, the majority of soil organic carbon is typically found in the top 1m of soil (Brady and Weil, 2004), while in agricultural soils most of the short- to medium-term management-related changes in organic carbon content occur in the upper 10-20 cm (Dick et al., 1986). For sites disturbed by mining activities, it is likely that changes in soil organic carbon concentrations are also concentrated in the surface soil horizons (Malik and Scullion, 1998; Shrestha and Lal, 2007; Ussiri et al., 2006).

Bulk density samples were also collected from the top $4 \mathrm{~cm}$ of soil at each site sampled for soil carbon content. Analysis for all soil parameters was segregated by the soil sample depth of collection. Dry composite samples were sifted to $<2 \mathrm{~mm}$ and analyzed for $\% \mathrm{C}$ and $\% \mathrm{~N}$ by weight using a automated dry combustion analyzer (Model 2400 Series II Analyzer, Perkin Elmer Inc., Waltham, MA). Soil pH was determined after Thomas (1996). Soils from zones and depths with $\mathrm{pH}$ readings $>7.0$ were acidified prior to dry combustion analysis following Ryba and Burgess (2002). Soils were screened from coal contamination by excluding high outliers in \%C or C:N (Insam and Domsch, 1988). The per-layer soil carbon storage at each site was calculated using the site-specific measurements of \%C and soil bulk density in the following formula (Ellert et al., 2001):

$$
\mathrm{SCS}=\mathrm{C}_{\mathrm{a}} \times \mathrm{t}_{\mathrm{a}} \times \mathrm{D}_{\mathrm{b}} \times 10^{2}
$$

where:

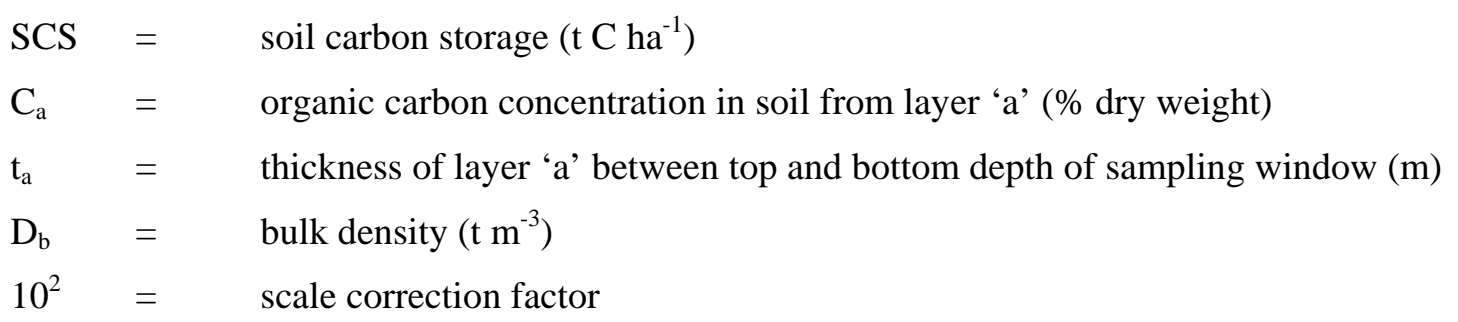

This method for estimating per-ha carbon storage approximates the mass of carbon that exists in each soil slab of thickness ' $t$ ' according to the within-layer mean \%C. Site-specific surface bulk density measurements were used to approximate the whole-slab bulk density in both soil layers in order to complete the calculation.

Changes in carbon storage between biosolids-amended and conventionally reclaimed mine soils were assumed to be zero unless statistically significant differences could be demonstrated from the collected field data. SPSS (version 16.0) was used to compare means in carbon storage in conventionally reclaimed and biosolids-amended sites using independent samples T-test to a level of significance of $p<0.05$ ( $p$ values corrected for unequal variances when necessary).

\section{$3 \quad$ Results}

\subsection{Field Study}

In the upper $15 \mathrm{~cm}$ soil layer, biosolids-amended sites stored significantly more carbon than conventionally reclaimed sites at every mine area sampled. Mean carbon storage in soils after biosolids amendment was elevated by varying degrees at each mine area over the means for conventionally reclaimed soils (Table 1). The 
concentration of carbon $(\% \mathrm{C})$ was also significantly higher in all the biosolids-amended mine sites (data not shown). Averaged across all mine areas sampled, sites reclaimed with biosolids stored an average of $32.47 \pm 3.16 \mathrm{t} \mathrm{C} \mathrm{ha}^{-1}$ more in the top $15 \mathrm{~cm}$ of soil than sites reclaimed conventionally. Mean carbon storage in the top $15 \mathrm{~cm}$ layer and mean differences in top-layer carbon storage between conventional and biosolidsamended sites varied significantly between the different mining areas (Figure 1).

Table 1 Summary of site reclamation treatments and increase in soil C storage in top $15 \mathrm{~cm}$ layer with biosolids amendment.

\begin{tabular}{|c|c|c|c|}
\hline Mine Area & Reclamation Soil Treatment & $\begin{array}{l}\text { Years Since } \\
\text { Reclamation }\end{array}$ & $\begin{array}{l}\text { Mean Soil C Increase } \\
\text { With Biosolids (t C ha } \text { ha }^{-1}\end{array}$ \\
\hline $\begin{array}{l}\text { Coal, central } \\
\text { Washington }\end{array}$ & $\begin{array}{l}\text { Topsoil only; or topsoil + } 560 \text { dry t } \\
\text { ha }^{-1} \text { biosolids }\end{array}$ & $17-31$ & 15.5 \\
\hline Copper, interior BC & $\begin{array}{l}\text { NPK fertilizer; or 133-138 dry t ha-1 } \\
\text { biosolids }\end{array}$ & $4-8$ & 38.4 \\
\hline $\begin{array}{l}\text { Sand/gravel, coastal } \\
\text { BC }\end{array}$ & $\begin{array}{l}\text { Estimated topsoil/spoil benchmark; } \\
\text { or } 50-102 \text { dry t ha }{ }^{-1} \text { biosolids }\end{array}$ & $4-8$ & 29.0 \\
\hline $\begin{array}{l}\text { Coal, eastern and } \\
\text { central Pennsylvania }\end{array}$ & $\begin{array}{l}\text { Topsoil + NPK fertilizer; or topsoil + } \\
\text { 128-337 dry t ha }{ }^{-1} \text { mine mix } \\
\text { (biosolids/sawdust) }\end{array}$ & $5-27$ & 23.3 \\
\hline $\begin{array}{l}\text { Sand/gravel, New } \\
\text { England }\end{array}$ & $\begin{array}{l}\text { Topsoil + NPK fertilizer; or } \\
\text { manufactured topsoil w/ } 617 \mathrm{t} \mathrm{ha}^{-1} \\
\text { added organic matter ( } 81 \text { dry t ha }{ }^{-1} \\
\text { biosolids) }\end{array}$ & $2-7$ & 87.5 \\
\hline
\end{tabular}

In the 15-30 cm layer of soil there were generally small increases in the calculated carbon storage (t C ha-1) and in measured carbon concentration $(\% \mathrm{C})$ between biosolids-amended and conventionally reclaimed sites, but these increases were not significant $(p>0.05)$.

\subsection{Life-cycle assessment of biosolids in land reclamation}

The life-cycle assessment incorporated the findings of the field research as well as other published studies on biosolids effects in soil (e.g. increases in plant growth and soil emissions of GHG). The assessment also took into account estimates of industrial, ecological and practical parameters appropriate to biosolids management, for instance expected hauling distance, material inputs required, equipment fuel efficiency and biosolids application rate. An attempt was made to take into account each activity that resulted in significant output or capture of GHG. A summary of the life-cycle assessment methodology and description of model construction and parameter estimation are available in Trlica (2010).

The assessment compared GHG emissions outcomes from utilizing a set amount of biosolids (100 dry t) generated in the Seattle area in two different land management contexts, evaluated for their effects over a period of 30 years (summary in Table 2). In the Biosolids Reclamation scenario, biosolids were assumed to be applied to replacement topsoil at 100 dry $\mathrm{t} \mathrm{ha}^{-1}$ to a parcel of degraded land in the western Cascade mountains, which was then replanted to native conifer forest. In the alternate Conventional Reclamation scenario, the reclamation parcel was assumed to be reclaimed with topsoil replacement only followed by reforestation, while the parcel of biosolids were assumed to be trucked to dryland wheat fields on the Columbia Plateau and applied at an agronomic rate for crop production (approximately $7.8 \mathrm{dry} \mathrm{t} \mathrm{ha-1}$ ), a common present-day practice for biosolids utilization in the region 


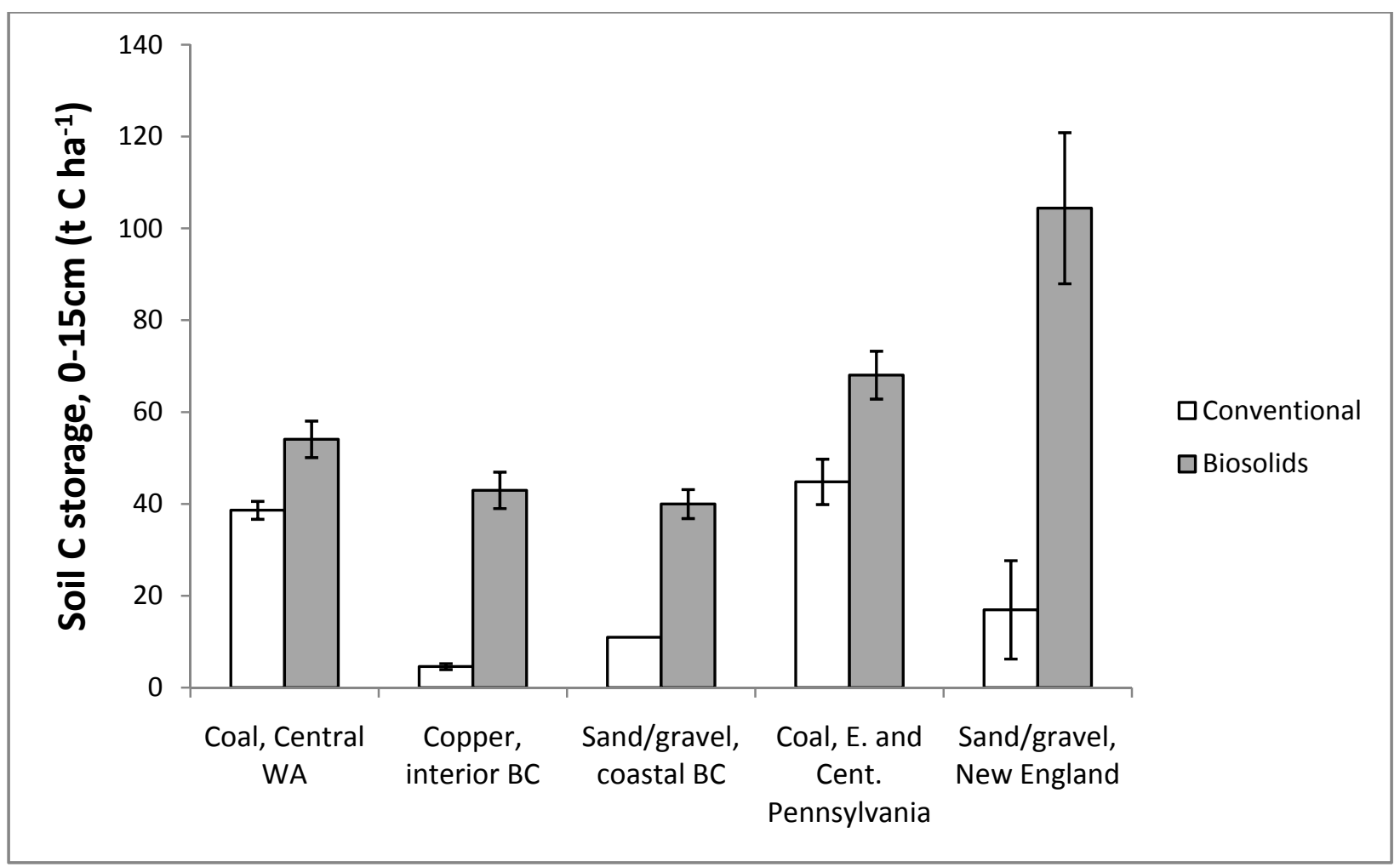

Figure 1: Mean organic carbon storage in the top $15 \mathrm{~cm}$ soil layer of reclaimed mine areas (error bars show standard error of the mean).

The life-cycle analysis scenarios were chosen because of their relevance to biosolids management in King County, Washington (which includes the Seattle metropolitan area) where biosolids have been land applied in the contexts of both mine reclamation and dryland wheat field fertilization, though the life-cycle GHG consequences of either use option had not previously been estimated. For both scenarios, important parameters and assumptions were determined based on real-world management experience (e.g. haul distances to application sites), or on the best available reported information (e.g. GHG intensity of manufactured inputs; soil and plant response to biosolids).

Table 2: Summary of assumptions for life cycle assessment scenarios

\begin{tabular}{lll}
\hline Assumption & Biosolids Reclamation & Conventional Reclamation \\
\hline $\begin{array}{l}\text { Biosolids trucking distance } \\
\begin{array}{l}\text { Amendment applied to } \\
\text { reclamation site }\end{array}\end{array}$ & $100 \mathrm{~km}$ & $300 \mathrm{~km}$ \\
$\begin{array}{l}\text { Source of nitrogen } \\
\text { supplement in wheat fields }\end{array}$ & Ammonia fertilizer & Biosolids $\left(7.8\right.$ dry t ha $\left.{ }^{-1}\right)$ \\
$\begin{array}{l}\text { Tree biomass growth rate at } \\
\text { reclamation site (30 years) }\end{array}$ & $150 \mathrm{t} \mathrm{ha}^{-1}$ & $100 \mathrm{t} \mathrm{ha}^{-1}$ \\
$\begin{array}{l}\text { Net C accumulation in } \\
\text { reclaimed soil (30 years) }\end{array}$ & $\left.50 \mathrm{t} \mathrm{C} \mathrm{ha}^{-1}\right)$ & None \\
$\begin{array}{l}\text { Net C accumulation in } \\
\text { cropland soil (30 years) }\end{array}$ & $0 \mathrm{t} \mathrm{ha}^{-1}$ & $40 \mathrm{t} \mathrm{C} \mathrm{ha}^{-1}$ \\
\hline
\end{tabular}


Parameters were intentionally selected from the range of results from above field study and reported in the scientific literature to conservatively underestimate the effect of biosolids on soil and plant carbon storage. For instance, the smallest increase in carbon storage in the top $15 \mathrm{~cm}$ with biosolids-amendment measured in this study was $15.5 \mathrm{t} \mathrm{C} \mathrm{ha}^{-1}$ but for the purposes of the lifecycle analysis was assumed to be $10 \mathrm{t} \mathrm{C} \mathrm{ha-1}$, and in the 15$30 \mathrm{~cm}$ layer sites was assumed to be zero given that no significant differences were detected in this soil layer.

Under either scenario the life-cycle assessment accounted for activities and emissions in both land parcels simultaneously, given the tradeoffs and substitutions necessary when biosolids were shifted from one use to the other. For instance, under the scenario of biosolids in reclamation it was assumed that manufacture of nitrogen fertilizer was required for use in the wheat fields, while in the biosolids to wheat field scenario it was assumed that carbon storage in the cropland soils increased (Kurtz, 2010) and that tree growth rate and soil carbon storage was lower in the reclamation site in the absence of biosolids.

Table 3: Greenhouse gas emission (or reductions) in alternative biosolids utilization scenarios, in tonnes $\mathrm{CO}_{2}$ equivalents (negative numbers indicate net reduction in greenhouse gas emissions).

\begin{tabular}{lll}
\hline Activity/Process & $\begin{array}{l}\text { Biosolids } \\
\text { Reclamation }\end{array}$ & $\begin{array}{l}\text { Conventional } \\
\text { Reclamation }\end{array}$ \\
\hline $\begin{array}{l}\text { Net capture of } \mathrm{CO}_{2} \text { in trees and soil } \\
\text { at reclamation site }\end{array}$ & -568 & -422 \\
Net capture of $\mathrm{CO}_{2}$ in cropland soil & 0 & -91 \\
Transport/handling of biosolids & 5 & 16 \\
Soil $\mathrm{N}_{2} \mathrm{O}$ release & 24 & 19 \\
Fertilizer production emissions & 0.2 & 0 \\
Net GHG balance & -539 & -477 \\
\hline
\end{tabular}

The outcome of the life-cycle assessment implies that the use of biosolids in land reclamation in the King County area with return to forest may produce greater net sequestration of GHG (62 t $\mathrm{CO}_{2}$ eq.) than use in dryland wheat fertilization (Table 3). The main GHG benefit of biosolids utilization in mine reclamation was that sites reclaimed with biosolids stored more biogenic $\mathrm{CO}_{2}$ in both on-site soil organic carbon pools and through enhanced rate of biomass accumulation in the growing trees. Emissions of GHG in other activity categories, for instance in transport-related emissions due to differences in biosolids haul distance, were not significant contributors to net GHG outcomes in comparison to the ecosystem-level carbon storage differences created by using biosolids in reclamation.

\section{Conclusions}

Biosolids used as a soil amendment during reclamation of areas degraded by surface mining resulted in significant increases in soil carbon storage that were persistent on the scale of decades. The differences between mines in overall soil carbon storage were likely due to variations in initial mine spoil properties, reclamation history (including replacement topsoil quality), regional climate and vegetation cover. These findings indicate the need to evaluate soil carbon storage on a region-specific basis, given the potentially large influence of local site factors.

An important goal of this study was to ascertain the degree to which increases in soil carbon with biosolids amendment persist for long periods of time. The duration factor is relevant to the suitability of using biosolids soil amendment projects for generating tradable emissions offsets, as the "permanence" of emissions reductions or sequestration is very often a key consideration in evaluating the credibility of GHG offsets projects. While we 
would expect that over the very long term conventionally reclaimed and biosolids-amended sites should stabilize at a similar average $\mathrm{C}$ storage, all other soil formation factors being equal, the sites examined in this study had apparently not equilibrated even up to 31 years after reclamation. Soil carbon increases due to biosolids amendment may therefore prove to be persistent enough to satisfy the requirement of permanence in relation to GHG offset credit production.

Life-cycle assessment is a tool capable of taking into account the effect of biosolids in increasing long-term soil carbon storage, as well as other practical differences between realistic biosolids utilization scenarios. Based on realistic assumptions for the life-cycle of land utilization of biosolids in the Puget Sound region, using biosolids to promote soil and forest recovery on degraded sites resulted in the more favorable GHG outcome of either potential utilization pathway considered. This outcome was primarily a product of greater soil carbon storage and increased plant growth rate resulting from biosolids use.

Biosolids management choices and the use of biosolids in mine closure both may play a part in reducing global GHG emissions (Brown and Leonard, 2004; Brown and Subler, 2007). Using biosolids in mine reclamation is a utilization pathway that can allow mine operators to participate in reducing climate change, meet their commitments to effective land stewardship, and capture the environmental benefits of utilizing an inexpensive and widely available product. Biosolids utilization in mine reclamation therefore represents an opportunity for partnership between biosolids generators and mine operators, with the potential for cost-effective and successful biosolids management and mine closure that comes with significant GHG benefits.

\section{Acknowledgements}

This research was completed during Mr. Trlica's master's thesis work conducted under the direction of Dr. Sally Brown at the College of the Environment at University of Washington, and included important advisory input from Dr. Scott Subler of Environmental Credit Corp. and Dr. Joyce Cooper of the University of Washington's Department of Mechanical Engineering. Funding for the research was provided by Mr. Jim Ellis of Seattle.

\section{References}

Akala, V.A. and Lal R. (2001) Soil organic carbon pools and sequestration rates in reclaimed minesoils in Ohio, Journal of Environmental Quality 30, pp. 2098-2104.

Amichev, B.Y., Burger, J.A. and Rodrigue, J.A. (2004) Carbon sequestration by forests and soils on mined land in the midwestern and Appalachian coalfields: Preliminary results, in Proceedings of the 21st Meeting of the American Society for Mining and Reclamation, and 25th West Virginia Surface Mine Drainage Task Force Symposium, R.I. Barnhisel (ed), April 18-22, 2004, American Society of Mine Reclamation, 3134 Montavesta Rd., Lexington, KY, pp. 20-46.

Bowen, C.K., Schuman, G.E., Olson, R.A. and Ingram, L.J. (2005) Influence of topsoil depth on plant and soil attributes of 24-year old reclaimed mined lands. Arid Land Research and Management 19, pp. 267-284.

Brady, N.C. and Weil, R.R. (2004) Elements of the Nature and Properties of Soils ( $2^{\text {nd }}$ ed.) Prentice Hall, New Jersey.

Brown, S.L., Henry, C.L., Chaney, R., Compton, H., and DeVolder, P.S. (2003) Using municipal biosolids in combination with other residuals to restore metal-contaminated mining areas, Plant and Soil 249, pp. 203-215.

Brown, S. and Leonard, P. (2004) Building carbon credits with biosolids recycling: Part II, Biocycle, September, pp. 25-29.

Brown, S. and Subler, S. (2007) Generating carbon credits through mine site restoration with organic amendments, in Mine Closure 2007: Proceedings of the Second International Seminar on Mine Closure, A. Fourie, M. Tibbett \& J. Wiertz (eds), 16-19 October 2007, Santiago, Chile, Salviat Impresores, Santiago, Chile, pp. 459-464.

Canadell, J.G., Le Quéré, C., Raupach, M.R., Field, C.B., Buitenhuis, E.T., Ciais, P., Conway, T.J., Gillett, N.P., Houghton, R.A. and Marland, G. (2007) Contributions to accelerating atmospheric $\mathrm{CO}_{2}$ growth from economic activity, carbon intensity, and efficiency of natural sinks, Proceedings of the National Academy of Science 104(47), pp. 18866-18870.

Dick, W.A., Van Doren, D.M. Jr., Tripplett, G.B, Jr. and Henry, J.E. (1986) Influence of long-term tillage and rotation combination on crop yields and selected soil parameters: Results obtained from a Mollic Ochraqualf soil. Ohio Agricultural Research and Development Center Research Bulletin 1181, Wooster, OH.

Ellert, B.H., Janzen, H.H. and McConkey, B.G. (2001) Measuring and comparing soil carbon storage, in Assessment Methods for Soil Carbon, R. Lal (ed), CRC Press, Boca Raton, FL, pp. 131-146. 
Haering, K.C, Daniels, W.L. and Feagley, S.E. (2000) Reclaiming mined lands with biosolids, manures, and papermill sludges, in Reclamation of Drastically Disturbed Lands, R.I. Barnhisel, R.G. Darmody and W.L. Daniels (eds), American Society of Agronomy, Inc., Crop Science Society of America, Inc., Soil Science Society of America, Inc., Madison, WI, pp. 615-644.

Haering, K.C., Daniels, W.L. and Galbraith, J.M. (2004) Appalachian mine soil morphology and properties: Effects of weathering and mining method, Soil Science Society of America Journal 68, pp. 1315-1325.

Indorante, S.J., Jansen, I.J. and Boast, C.W. (1981) Surface mining and reclamation: Initial changes in soil character, Journal of Soil \& Water Conservation 36(6), pp. 347-351.

Insam, H. and Domsch, K.H. (1988) Relationship between soil organic carbon and microbial biomass on chronosequences of reclamation sites, Microbial Ecology 15, pp. 177-188.

Jacinthe, P.-A. and Lal, R. (2007) Carbon storage and minesoil properties in relation to topsoil application techniques, Soil Science Society of America Journal 71, pp. 1788-1795.

Kurtz, K.E. (2010) Quantification of the long-term effects of organic soil amendment use: carbon, nitrogen, bulk density, and water-holding capacity, Master's thesis, School of Forest Resources, University of Washington, Seattle, WA.

Malik, A. and Scullion, J. (1998) Soil development on restored opencast coal sites with particular reference to organic matter and aggregate stability. Soil Use and Management 14, pp. 234-239.

Murray, A., Horvath, A. and Nelson, K.L. (2008) Hybrid life-cycle environmental and cost inventory of sewage sludge treatment and end-use scenarios: a case study from China. Environmental Science \& Technology 42(9), pp. 3163316.

Orndorff, Z.W., Daniels, W.L. and Fanning, D.S. (2008) Reclamation of acid sulfate soils using lime-stabilized biosolids, Journal of Environmental Quality 37, pp. 1447-1455.

Pacala, S. and Socolow, R. (2004) Stabilization wedges: Solving the climate problem for the next 50 years with current technology, Science 305(5686), pp. 968-972.

Roberts, J.A., Daniels, W.L., Bell, J.C. and Burger, J.A. (1988) Early stages of mine soil genesis as affected by topsoiling and organic amendments, Soil Science Society of America Journal 52, pp. 730-738.

Ryba, S.A. and Burgess, R.M. (2002) Effects of sample preparation on the measurement of organic carbon, hydrogen, nitrogen, sulfur, and oxygen concentrations in marine sediments, Chemosphere 48, pp. 139-147..

Sencindiver, J.C. and Ammons, J.T. (2000) Minesoil genesis and classification, in Reclamation of Drastically Disturbed Lands, R.I. Barnhisel, R.G. Darmody and W.L. Daniels (eds), American Society of Agronomy, Inc., Crop Science Society of America, Inc., Soil Science Society of America, Inc., Madison, WI, pp. 595-614.

Shrestha, R.K. and Lal, R. (2007) Soil carbon and nitrogen in 28-year-old land uses in reclaimed coal mine soils of Ohio. Journal of Environmental Quality 36, pp. 1775-1783.

Shukla, M.K., Lal, R. and Ebinger, M.H. (2005) Physical and chemical properties of a minespoil eight years after reclamation in Northeastern Ohio. Soil Science Society of America Journal 69, pp. 1288-1297.

Sopper, W.E. (1993) Municipal Sludge Use in Land Reclamation, CRC Press, LLC. Boca Raton, FL.

Thomas, G.W. (1996) Soil pH and soil acidity, in Methods of Soil Analysis: Part 3, Chemical methods, Soil Science Society of America, Inc., Madison, WI, pp. 475-490.

Tian, G., Granato, T.C., Cox, A.E., Pietz, R.I., Carlson, C.R. Jr. and Abedin, Z. (2009) Soil carbon sequestration resulting from long-term application of biosolids for land reclamation, Journal of Environmental Quality 38, pp. 61-74.

Trlica, A. (2010) Mitigation of climate change through land reclamation with biosolids: Carbon storage in reclaimed mine soils, life cycle analysis of biosolids reclamation, and ecosystem services with reforestation, Masters thesis, School of Forest Resources, University of Washington, Seattle, WA, 248 p.

Ussiri, D.A.N., Lal, R., and Jacinthe, P-.A. (2006) Soil properties and carbon sequestration of afforested pastures in reclaimed minesoils of Ohio. Soil Science Society of America Journal 70, pp. 1797-1806. 